\title{
Circulating progesterone, progesterone-binding proteins and oestradiol-17ß concentrations in the pregnant Cape porcupine, Hystrix africaeaustralis
}

\author{
R. J. van Aarde and H. C. Potgieter* \\ Mammal Research Institute and ${ }^{*}$ Nucor Institute of Life Sciences, University of Pretoria, \\ Pretoria 0002, South Africa
}

\begin{abstract}
Summary. Circulating concentrations of progesterone, progesterone-binding plasma proteins (PBPP) and oestradiol-17 $\beta$ in pregnant porcupines remained relatively low until Days 25-30 post coitum. Progesterone values peaked (102-180 ng/ml; N=3) 42-60 days post coitum and the rapid increase in oestradiol-17ß concentrations approximated that of progesterone with peak values $(170-210 \mathrm{pg} / \mathrm{ml})$ being attained 60-85 days post coitum. The pattern of PBPP synthesis, as suggested by circulating concentrations, was closely related to that of plasma progesterone, with values remaining low $(<20 \mathrm{pmol} / \mathrm{ml})$ until Day 31 post coitum, reaching peak levels at Days $50-56$ and Days 73-77 post coitum. The production of PBPP during pregnancy is, as in related New World hystricomorph species, considered to be a mechanism which facilitates a reduction in the rate of progesterone metabolism during pregnancy.
\end{abstract}

\section{Introduction}

No published information is available on the endocrinology of pregnancy of Old World porcupines (Family Hystricidae). The reproductive characteristics of the Cape porcupine (Hystrix africaeaustralis) conform to those of New World hystricomorph rodents: females are polyoestrous, conceive only once a year and pregnancy lasts 93-94 days (van Aarde, 1984, 1985a).

Circulating concentrations of progesterone in New World hystricomorph rodents are higher than those recorded in other rodents and most other mammals (Tam, 1974). Mechanisms involved in supplementing the production of progesterone by the primary corpora lutea include the formation of accessory corpora lutea, the assumption of an endocrine role by the placenta (Tam, 1974) and the production of high-affinity binding proteins (Heap \& Illingworth, 1974). High-affinity progesterone-binding proteins have been identified in several New World hystricomorph rodents, but were not detected in murids, rabbits, ferrets, pigs, sheep or women (Heap \& Illingworth, 1974; Heap, Ackland \& Weir, 1981). The production of these proteins apparently buffers the effects of rapid steroid metabolism.

The present paper reports on plasma concentrations of progesterone, progesterone-binding proteins and oestradiol-17 $\beta$ in captive porcupines throughout pregnancy.

\section{Materials and Methods}

Blood samples. Females housed with males in semi-outdoor concrete enclosures at the University of Pretoria as described by van Aarde (1985a, b) were immobilized at 2-7-day intervals through an intramuscular injection of a mixture of $75 \mathrm{mg}$ ketamine hydrochloride (Ketalar: Parke-Davis (Pty) Ltd, Isando, South Africa) and $20 \mathrm{mg}$ xylazine hydrochloride (Rompun: Bayer Pharmaceuticals, Johannesburg, South Africa). Heparinized blood samples $(5.0 \mathrm{ml})$ were collected between 10:00 and 12:00 $\mathrm{h}$ by cardiac puncture. Blood was centrifuged for $10 \mathrm{~min}$ and plasma was removed and stored at $-20^{\circ} \mathrm{C}$ until analysed. 
Determination of progesterone-binding plasma proteins ( $P B P P)$. A protocol modified from that developed by Heap et al. (1981) was used. Plasma samples were diluted 20 -fold in $10 \mathrm{mM}$-Tris-HC1 buffer ( $\mathrm{pH} 7 \cdot 4)$ to a final protein concentration of $2-3 \mathrm{mg} / \mathrm{ml}$. Duplicate samples $(0 \cdot 1 \mathrm{ml})$ of the diluted plasma were incubated with increasing amounts $(0 \cdot 125-4.0 \mathrm{nM})$ of $\left[17 \alpha-\right.$ methyl- $\left.{ }^{3} \mathrm{H}\right]$ promogestone $\left(\left[{ }^{3} \mathrm{H}\right] \mathrm{R} 5020\right.$; New England Nuclear, Boston, MA, U.S.A.) in the presence (to determine nonspecific binding) or absence (to determine total binding) of a 100 -fold excess promogestone (R5020, New England Nuclear) for $15 \mathrm{~min}$ at $37^{\circ} \mathrm{C}$ followed by an overnight incubation at $4^{\circ} \mathrm{C}$. The $5 \mathrm{ml}$ dextran-coated charcoal $(0.625 \%$ activated charcoal, Sigma, Dorset, U.K. and 0.0625\% dextran T40, Pharmacia, Uppsala, Sweden) in buffer were added to each tube and thoroughly mixed on a vortex mixer. After $15 \mathrm{~min}$ on ice, the tubes were centrifuged at $4^{\circ} \mathrm{C}$ and $3000 \mathrm{~g}$ for $15 \mathrm{~min}$. Aliquants $(0.5 \mathrm{ml})$ of supernatants were pipetted in scintillation vials and $4.0 \mathrm{ml}$ scintillation cocktail (Ready-Solve HB/b: Beckman Instruments (Pty) Ltd, Johannesburg, South Africa) were added. The amount of protein-bound radioactivity was measured in a Beckman LS 5800 scintillation counter.

Specific binding was calculated and plotted according to the method of Scatchard (1949). A single-point assay was subsequently developed to permit the simultaneous analysis of a large number of samples (Heap et al., 1981). Plasma protein concentrations were determined as described by Lowry, Rosebrough, Farr \& Randall (1951).

Radioimmunoassay of progesterone. Duplicate plasma aliquants $(0.01-0.05 \mathrm{ml})$ were extracted with $2.0 \mathrm{ml}$ petroleum ether (Saarchem (Pty) Ltd, Krugersdorp, South Africa) after the addition of $0.1 \mathrm{ml} \mathrm{NaOH}(600 \mathrm{~mm})$ to denature PBPP (Challis, Heap \& Illingworth, 1971). Progesterone was measured by the procedure described previously (Haresign, Foster, Haynes, Crighton \& Lamming, 1975; van Aarde, 1985c). Specificity of the antiserum (Specific Antisera Ltd, Wilmslow, U.K.) has been described by Furr (1973). Sensitivity of assays ranged from 0.16 to $0.73 \mathrm{ng} / \mathrm{ml}$ $(0.49 \pm 0.21 \mathrm{s.d}$; $n=7)$ and buffer blanks contained $0.46 \pm 0.26 \mathrm{ng}$ progesterone equiv. $/ \mathrm{ml}$. Heating of plasma pools from pregnant females $\left(30 \mathrm{~min}\right.$ at $\left.60^{\circ} \mathrm{C}\right)$ in an attempt to denature binding proteins did not improve recovery estimates ( $24 \cdot 1 \%$ compared with $24.7 \%$ for untreated samples) but the addition of $0.1 \mathrm{ml} \mathrm{NaOH} 10 \mathrm{~min}$ before extraction increased recovery estimates in the same samples to $69 \cdot 6 \pm 8 \cdot 9 \%$. Intra-and interassay coefficients of variation were 4.3 and $9 \cdot 7 \%$ respectively.

Radioimmunoassay of oestradiol $-17 \beta$. Duplicate plasma samples $(1.0 \mathrm{ml})$, reagent blanks and tritiated steroid recovery samples were extracted with $4.0 \mathrm{ml}$ diethyl ether (Merck, Darmstadt, F.R.G.) by shaking the mixtures thoroughly for $5 \mathrm{~min}$ on a multitube vortexer (Model 2601, Scientific Manufacturing Industries, Emeryville, U.S.A.). Oestradiol-17 $\beta$ concentration was measured by the procedure described by Abraham (1976) and van Aarde (1985c). Specificity of the antiserum raised in rabbits against oestradiol-6-(O-carboxymethyl)oxime-bovine serum albumin conjugate has been quantified by the supplier (R. P. Millar, Department of Chemical Pathology, University of Cape Town, South Africa) and cross-reactions of other steroids were: oestrone, $0.01 \%$; pregnanediol, corticosterone, deoxycorticosterone, $17 \alpha$-hydroxypregnenolone androstenedione, 20 $\alpha$-dihydroprogesterone, progesterone, testosterone and cortisol, $0.001 \%$. Sensitivity of 8 assays ranged from 3.7 to $15.8 \mathrm{pg} / \mathrm{ml}(11.7+3.9$ s.d.) and buffer blanks contained $8.3 \pm 2.8 \mathrm{pg}$ oestradiol-17 $\beta$ equiv. $/ \mathrm{ml}$. Extraction efficiency varied from $85 \cdot 1$ to $96 \cdot 8 \%(91 \cdot 4 \pm 4 \cdot 3$ s.d.; $n=8)$ and the amount of oestradiol- $17 \beta(25,50$ and $100 \mathrm{pg} / \mathrm{ml})$ recovered from pools of plasma from males did not differ significantly from expected values. Intra- and interassay coefficients of variation were 2.4 and $16.2 \%$ respectively. Interassay variation for a sample containing $32 \cdot 6 \pm 3 \cdot 1 \mathrm{pg} / \mathrm{ml}$ oestradiol $-17 \beta$ was $9 \cdot 4 \%$.

\section{Results}

Progesterone and oestradiol-17 $\beta$

Circulating concentrations of progesterone in pregnant porcupines remained relatively low 
( $\sim 20 \mathrm{ng} / \mathrm{ml}$ ) until Days 25-30 post coitum, increasing sharply thereafter to peak at 42-60 days post coitum (102-180 ng/ml; $\mathrm{N}=3$ ) (Fig. 1). Progesterone concentrations decreased gradually during the last 30 days of pregnancy and values on Day 85 post coitum ( $8-9$ days pre partum) varied from $49 \cdot 3$ to $100 \mathrm{ng} / \mathrm{ml}(77 \cdot 3 \pm 32 \cdot 3$ s.d.; $\mathrm{N}=4)$. Values in samples taken within 6 days after parturition varied from $0 \cdot 5$ to $7 \cdot 1 \mathrm{ng} / \mathrm{ml}(2 \cdot 6 \pm 3 \cdot 1 ; \mathrm{N}=4)$. Progesterone concentrations during matings

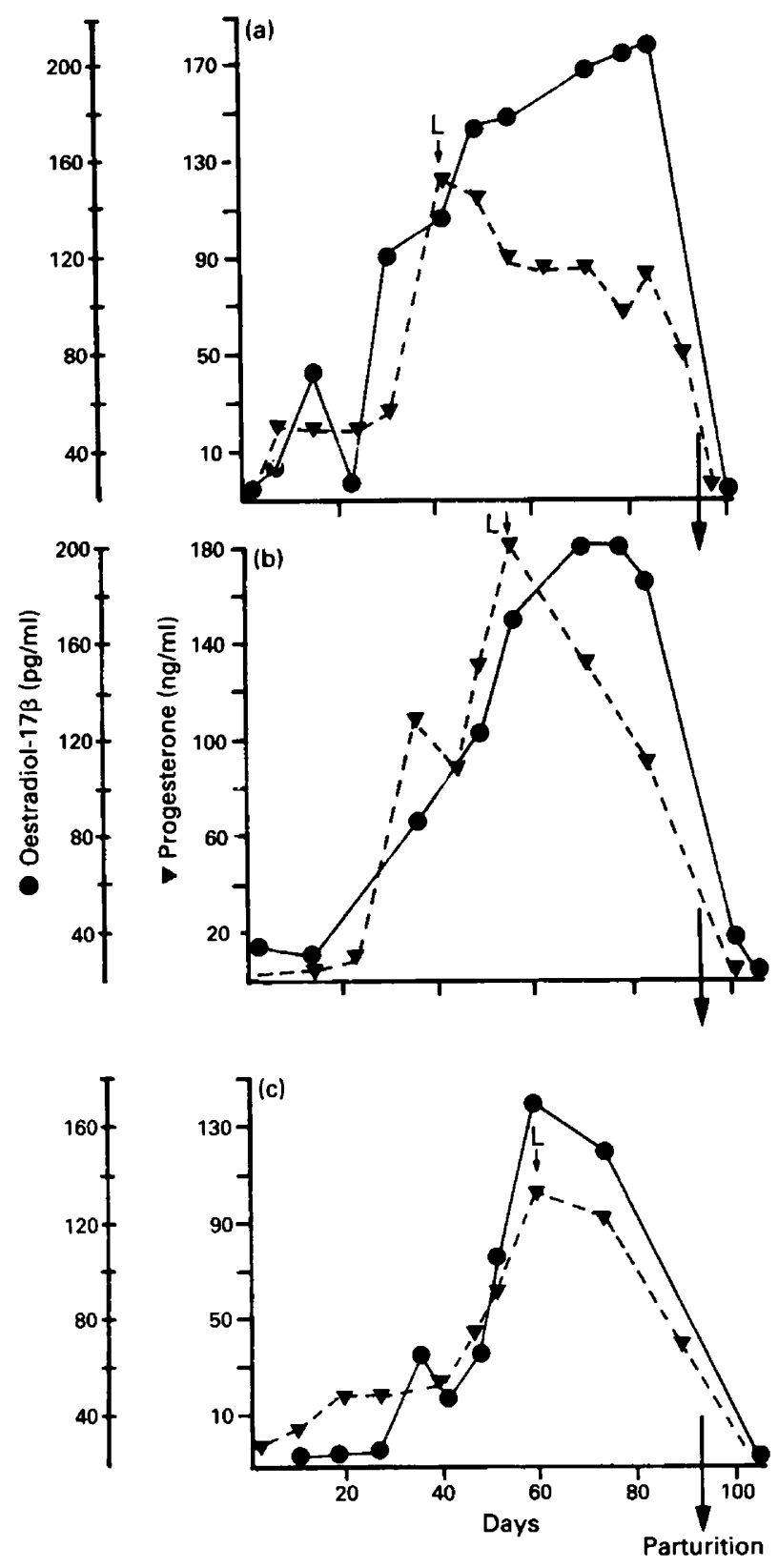

Fig. 1. Plasma progesterone $(\nabla)$ and oestradiol-17 $\beta(\odot)$ concentrations throughout pregnancy in 3 captive female porcupines. $L$ denotes the day when milk could be expressed from the teats and the arrows indicate the day of parturition. 
followed by conception varied from 2.0 to $4.1 \mathrm{ng} / \mathrm{ml}(3.2 \pm 1.0$ s.d.; $\mathrm{N}=3)$ and were significantly higher $(P<0.01)$ than values observed $(0.5-1.5 \mathrm{ng} / \mathrm{ml} ; 0.9 \pm 0.5 \mathrm{s.d}$.; $\mathrm{N}=6)$ on days of 'sterile' matings (matings with intact males that were not followed by pregnancy).

Oestradiol- $17 \beta$ concentrations at conception varied from 22.0 to $34.0 \mathrm{pg} / \mathrm{ml}(25.3 \pm 7.6 \mathrm{s.d}$; $\mathrm{N}=3$ ) and remained relatively low until Days 20-25 post coitum (Fig. 1). The rapid increase in oestradiol-17 $\beta$ concentrations approximated that of progesterone with peak values $(170-210 \mathrm{pg} / \mathrm{ml}$ ) being attained $60-85$ days post coitum (Fig. 1). Oestradiol-17 $\beta$ values on Day 85 post coitum varied from 185 to $210 \mathrm{pg} / \mathrm{ml}$, decreasing to the limits of detection $(\sim 10 \mathrm{pg} / \mathrm{ml})$ within 6 days after parturition.

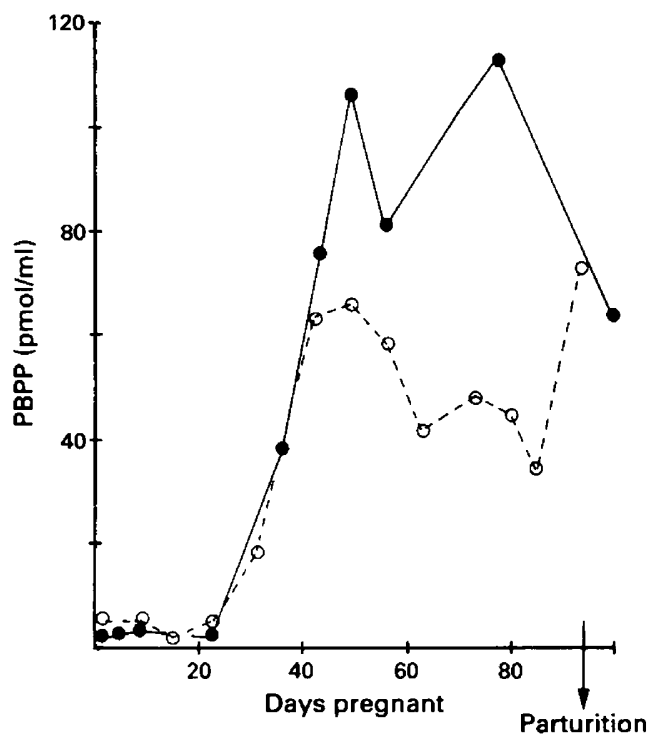

Fig. 2. Circulating concentrations of progesterone-binding plasma proteins (PBPP) in 2 pregnant porcupine females $(\bullet, \bigcirc)$ throughout pregnancy.

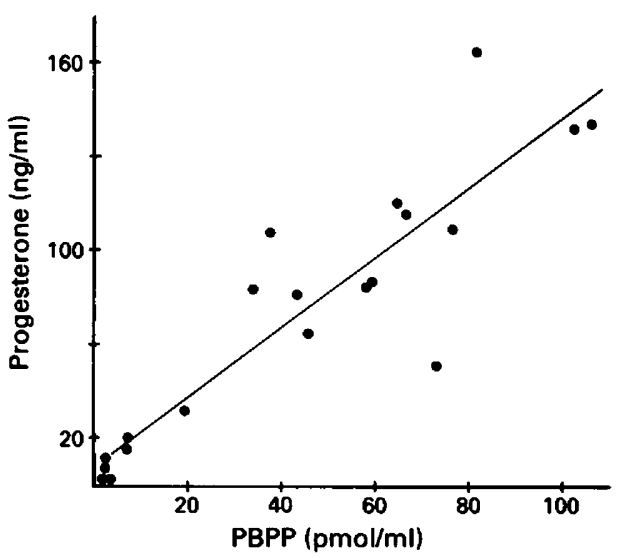

Fig. 3. The relationship between circulating concentrations of plasma progesterone and circulating levels of progesterone-binding plasma proteins (PBPP). The line, fitted through linear least square regression analysis, is described by the equation $y=29 \cdot 27 x+9 \cdot 70$. 


\section{Progesterone-binding plasma proteins (PBPP)}

The PBPP exhibited a high binding affinity (mean $K_{\mathrm{d}}=1 \cdot 2 \pm 0.3 \times 10^{-9} \mathrm{M} ; n=10$ ) but saturable binding capacity (20-114.2 pmol/ml; 319-2053 fmol/mg protein). Concentrations of PBPP for 2 pregnant females from which serial plasma samples were available showed a biphasic pattern, with peaks occurring between Days 50-56 and Days 73-77 post coitum (Fig. 2), but PBPP levels remained low ( $<20 \mathrm{pmol} / \mathrm{ml} ;<319 \mathrm{fmol} / \mathrm{mg}$ protein) until Day 31 post coitum, thereafter increasing rapidly to the first $(65.6-105.9 \mathrm{pmol} / \mathrm{ml} ; 1025-2053 \mathrm{fmol} / \mathrm{mg}$ protein) and second $(58 \cdot 6-114 \cdot 2 \mathrm{pmol} / \mathrm{ml} ; 1085-2139 \mathrm{fmol} / \mathrm{mg}$ protein) peaks. Values remained relatively high $(64.7 \mathrm{pmol} / \mathrm{ml} ; 1216 \mathrm{fmol} / \mathrm{mg}$ protein) until after parturition, but were below $20.0 \mathrm{pmol} / \mathrm{ml}$ (342 fmol/mg protein) at 16 days after birth (Fig. 2).

Progesterone values $(\mathrm{ng} / \mathrm{ml})$ increased linearly and significantly $\left(r^{2}=0.81\right)$ with an increase in PBPP values (pmol/ml; Fig. 3). The molar ratio of PBPP concentrations to progesterone remained below unity throughout pregnancy but increased approximately 10-fold after Day 31 post coitum and remained relatively high $(0 \cdot 164-0 \cdot 222)$ throughout the remainder of pregnancy.

\section{Discussion}

Basal levels of progesterone at the time of matings which culminated in pregnancies were significantly higher than those recorded during 'sterile' matings, thereby suggesting that priming of the reproductive tract by progesterone may be required for conception, either before, during or after the oestradiol-17 $\beta$ surge. Gestation lengths in hystricomorphs vary considerably but are longer than those predicted for their body sizes (Weir, 1974). In the porcupine (gestation length 93-94 days) the initial period of pregnancy (0-25 days post coitum) is, as in the guinea-pig (Challis et al., 1971), cuis, Galea musteloides (Tam, 1973), and coypu, Myocastor coypus (Rowlands \& Heap, 1966), characterized by relatively low levels of circulating progesterone when compared to values during later stages of pregnancy. Progesterone values increased rapidly between Days 25 and 40 post coitum and attained maximum values 50-60 days after mating. Rapid increases in progesterone concentrations in guinea-pigs after the 15th day of pregnancy are due to decreased progesterone metabolic clearance rate (Illingworth, Heap \& Perry, 1970). Similar increases in the coypu have been ascribed to a $90 \%$ decrease in metabolic clearance rate, accompanied by a 3-6-fold increase in progesterone production (Heap \& Illingworth, 1974). Progesterone-binding globulins (PBG) are present in several pregnant hystricomorph rodent species and in the guinea-pig sharp increases in PBG levels coincide with the time when a definite placenta is established (Heap et al., 1981). This is, however, not the situation in pregnant casiragua (Proechimys guairae) in which PBPP started to increase after the formation of the placenta. In the degu, Octodon degus, and plains viscacha, Lagostomus maximum, levels of these proteins increase before the formation of the placenta (Heap et al., 1981).

The presence of high-affinity progesterone-binding proteins in plasma of pregnant porcupines was established, after persistent poor extraction efficiency of $\left[{ }^{3} \mathrm{H}\right]$ progesterone from plasma pools, and subsequently identified by the technique described by Heap et al. (1981). The pattern of PBPP synthesis, as suggested by circulating values, was closely related to the circulating concentrations of progesterone in plasma. The temporal pattern of PBPP concentration differs between species, with the biphasic pattern observed in pregnant porcupines being similar to that observed in guinea-pigs (Heap et al., 1981). However, values in the pregnant porcupines throughout gestation were considerably lower than those recorded in the pregnant guinea-pig, casiragua, cuis, degu and viscacha (Heap et al., 1981).

It would appear that the production of high levels of PBPP during pregnancy in the porcupine provides a means of conserving progesterone with the onset of PBPP production occurring 31 days post coitum, resulting in a sharp increase in circulating progesterone concentrations. Heap et al. 
(1981) suggest that progesterone requirements of pregnancy in the New World hystricomorph rodents are met through the presence of a mechanism that ensures a substantial steroid pool which can dissociate rapidly from its carrier. This also seems to be true for the porcupine, an Old World hystricomorph rodent. PBPP may, however, also function to reduce the concentration of freely available progesterone in the blood and to provide a source of progesterone for target cell receptors.

Oestradiol-17 $\beta$ profiles throughout pregnancy in hystricomorph rodents, until now, have been published only for the guinea-pig (Challis et al., 1971), and peak values $(31 \cdot 0 \pm 5 \cdot 2 \mathrm{pg} / \mathrm{ml})$ were considerably lower than in the porcupine $(170-210 \mathrm{pg} / \mathrm{ml})$. Values for captive females sampled serially remained low until Days 20-25 post coitum and the rates of increase were similar to those of progesterone and PBPP. Oestradiol-17 $\beta$ values, however, remained high until before parturition, while progesterone concentrations were decreasing, and were also higher than those recorded for cyclic females (van Aarde, 1985c). The observed pattern of oestradiol-17 $\beta$ secretion during pregnancy in the porcupine, as a result of its sharp increase after the first 20-25 days of pregnancy, is at variance with that observed in most mammals, but similar to the pattern observed in pregnant guinea-pigs. Plasma oestrogen concentrations increase in most mammals during pregnancy (Bedford, Challis, Harrison \& Heap, 1972) and Austad, Lunde \& Sjaastad (1976) recorded significantly higher levels at mid-pregnancy in the bitch (Canis familiaris) than in the period after oestrus. Circulating levels of hormones do not necessarily reflect their rates of secretion and as yet nothing is known about the metabolism or production of steroids and the relative contribution of the ovary, uterus, placenta and conceptus in the porcupine.

Concentrations of corticosteroid-binding globulin (CBG) or transcortin, with its high affinity for progesterone, occur at extremely high levels in the plasma of pregnant guinea-pigs and are known to be related to high oestrogen concentrations in plasma (Heap \& Illingworth, 1974). Heating of plasma pools from pregnant porcupines at $60^{\circ} \mathrm{C}$ for $30 \mathrm{~min}$, which should destroy CBG binding of progesterone (Heap \& Illingworth, 1974) did not improve extraction efficiency of $\left[{ }^{3} \mathrm{H}\right]$ progesterone, thus suggesting that progesterone in porcupines binds to PBG (Heap et al., 1981) and not to $\mathrm{CBG}$ or that $\mathrm{CBG}$, if occurring as a result of increasing oestradiol-17$\beta$ levels, has functions other than binding progesterone.

Financial support was provided by the University of Pretoria, the Council for Scientific and Industrial Research and the Transvaal Branch of the Wildlife Society of Southern Africa who twice awarded one of us (R.J. van A.) the Charles Astley Memorial Scholarship. We thank Mr J. H. Spies, Mr D. Majola and Mrs M. Thierry for assistance.

\section{References}

Abraham, E.G. (1976) Radioimmunoassay of oestradiol-17ß. In Methods of Hormone Analysis, pp. 537-571. Eds H. Breuer, D. Hamel \& H. L. Krüskemper. George Thieme Verlag, Stuttgart.

Austad, R., Lunde, Astrid \& Sjaastad, O.v. (1976) Peripheral plasma levels of oestradiol-17 $\beta$ and progesterone in the bitch during the oestrous cycle, in normal pregnancy and after dexamethasone treatment. J. Reprod. Fert. 46, 129-136.

Bedford, C.A., Challis, J.R.G., Harrison, F.A. \& Heap, R.B. (1972) The role of oestrogens and progesterone in the onset of parturition in various species. $J$. Reprod. Fert., Suppl. 16, 1-23.

Challis, J.R.G., Heap, R.B. \& Illingworth, D.V. (1971) Concentrations of oestrogen and progesterone in the plasma of non-pregnant, pregnant and lactating guinea-pigs. J. Endocr. 51, 333-345.
Furr, B.J.A. (1973) Radioimmunoassay of progesterone in peripheral plasma of the domestic fowl in various physiological states and in follicular venous plasma. Acta endocr., Copenh. 72, 89-100.

Haresign, W., Foster, J.P., Haynes, N.B., Crighton, D.B. \& Lamming, G.E. (1975) Progesterone levels following treatment of seasonally anoestrous ewes with synthetic LH-releasing hormone. J. Reprod. Fert. 43, 269-279.

Heap, R.B. \& Illingworth, D.V. (1974) The maintenance of gestation in the guinea-pig and other hystricomorph rodents: changes in the dynamics of progesterone metabolism and the occurrence of progesterone-binding globulin (PBG). Symp. zool Soc. Lond. 34, 385-415.

Heap, R.B., Ackland, N. \& Weir, B.J. (1981) Progesterone-binding proteins in plasma of guinea-pigs 
and other hystricomorph rodents. J. Reprod. Fert. 63, 477-489.

Illingworth, D.V., Heap, R.B. \& Perry, J.S. (1970) Changes in metabolic clearance rate of progesterone in the guinea-pig. J. Endocr. 48, 408-417.

Lowry, O.H., Rosebrough, N.J., Farr, A.L. \& Randall, R.J. (1951) Protein measurement with the Folin phenol reagent. J. biol. Chem. 93, 265-275.

Rowlands, I.W. \& Heap, R.B. (1966) Histological observations on the ovary and progesterone levels of the coypu, Myocastor coypus. Symp. zool. Soc. Lond. 15, 335-352.

Scatchard, G. (1949) The attraction of proteins for small molecules and ions. Ann. N.Y. Acad. Sci. 51, $660-672$.

Tam, W.H. (1973) Progesterone levels during the oestrous cycle and pregnancy in the cuis. (Galea musteloides). J. Reprod. Fert. 35, 105-114.

Tam, W.H. (1974) The synthesis of progesterone in some hystricomorph rodents. Symp. zool. Soc. Lond. 34, 363-384. van Aarde, R.J. (1984) Reproduction in the porcupine Hystrix africaeaustralis Peters. D.Sc. Thesis, University of Pretoria.

van Aarde, R.J. (1985a) Reproduction in captive female Cape porcupines (Hystrix africaeaustralis). $J$. Reprod. Fert. 75, 577-582.

van Aarde, R.J. (1985b) Husbandry and immobilization of captive porcupines Hystrix africaeaustralis. S. Afr. J. Wildl. Res. 15, 77-79.

van Aarde, R.J. (1985c) Circulating progesterone and oestradiol-17\% concentrations in cyclic Cape porcupines, Hystrix africaeaustralis. J. Reprod. Fert. 75, 583-591.

Weir, B.J. (1974) Reproductive characteristics of hystricomorph rodents. Symp. zool. Soc. Lond. 34, 265-301. 